University of Nebraska - Lincoln

DigitalCommons@University of Nebraska - Lincoln

Runoff Losses of N and P After Low Phosphorus Swine Slurry Application to No-Tillage Sorghum

\author{
Brian J. Wienhold \\ University of Nebraska-Lincoln, Brian.Wienhold@ars.usda.gov \\ John E. Gilley \\ USDA-ARS, john.gilley@ars.usda.gov
}

Follow this and additional works at: https://digitalcommons.unl.edu/usdaarsfacpub

Wienhold, Brian J. and Gilley, John E., "Runoff Losses of N and P After Low Phosphorus Swine Slurry Application to No-Tillage Sorghum" (2010). Publications from USDA-ARS / UNL Faculty. 1211. https://digitalcommons.unl.edu/usdaarsfacpub/1211

This Article is brought to you for free and open access by the U.S. Department of Agriculture: Agricultural Research Service, Lincoln, Nebraska at DigitalCommons@University of Nebraska - Lincoln. It has been accepted for inclusion in Publications from USDA-ARS / UNL Faculty by an authorized administrator of DigitalCommons@University of Nebraska - Lincoln. 


\title{
Runoff Losses of N and P After Low Phosphorus Swine Slurry Application to No-Tillage Sorghum
}

\author{
Brian J. Wienhold and John E. Gilley
}

\begin{abstract}
Swine (Sus scrofa) manure can serve as a fertilizer source for crop production, but it typically contains more $P$ relative to $N$ than the crop requires, creating the potential for $\mathrm{P}$ losses in runoff. A 3-year study was conducted to compare runoff losses of $\mathrm{NO}_{3}-\mathrm{N}, \mathrm{NH}_{4}-\mathrm{N}$, total $\mathrm{N}$, dissolved $P$, and total $P$ under natural rainfall conditions from no-tillage sorghum plots [Sorghum bicolor (L.) Moench] receiving inorganic fertilizer, manure from swine fed low-phytate com (Zea mays L.) diet, or manure from swine fed a traditional corn diet. Runoff (26.5 mm in 1999. $14.2 \mathrm{~mm}$ in 2000 , and $1.6 \mathrm{~mm}$ in $200 \mathrm{l})$, sediment loss $\left(2.9 \mathrm{~kg} \mathrm{ha}^{-1}\right.$ in $1999.0 .9 \mathrm{~kg} \mathrm{ha}^{-1}$ in 2000 , and $0.4 \mathrm{~kg} \mathrm{ha}^{-1}$ in 2001 ), and runoff nutrient losscs diffcred among years but were similar among treatments within a year. Runoff losses of $\mathrm{NO}_{3}-\mathrm{N}\left(5.3 \mathrm{~g} \mathrm{ha}^{-1}\right.$ in $1999,1.0 \mathrm{~g} \mathrm{ha}^{-1}$ in 2000 , and $2.6 \mathrm{~g} \mathrm{ha}^{-1}$ in 2001). $\mathrm{NH}_{4}-\mathrm{N}\left(2.9 \mathrm{~g} \mathrm{ha}^{-1}\right.$ in $1999,0.6 \mathrm{~g} \mathrm{ha}^{-1}$ in 2000 , and $5.6 \mathrm{~g} \mathrm{ha}^{-1}$ in 2001$)$, total $\mathrm{N}\left(89.7 \mathrm{~g} \mathrm{ha}^{-1}\right.$ in $1999,8.4 \mathrm{~g} \mathrm{ha}^{-1}$ in 2000 , and $100.2 \mathrm{~g} \mathrm{ha}^{-1}$ in 2001), dissolved $P\left(1.5 \mathrm{~g} \mathrm{ha}^{-1}\right.$ in 1999 , $0.5 \mathrm{~g} \mathrm{ha}^{-1}$ in 2000 , and $3.1 \mathrm{~g} \mathrm{ha}^{-1}$ in 200.1$)$, and total $\mathrm{P}\left(3.8 \mathrm{~g} \mathrm{ha}^{-1}\right.$ in 1999, $0.9 \mathrm{~g} \mathrm{ha}^{-1}$ in 2000, and $3.5 \mathrm{~g} \mathrm{ha}^{-1}$ in 2001) from these plots represented less than $1 \%$ of that applied each year. Although use of low-phytate corn reduces manure P. content, it did not decrease runoff $\mathbf{P}$ under these no-tillage conditions.
\end{abstract}

Key words: Nutrient management, manure management, water quality, conservation tillage.

(Soil Sci 2010;175: 201-206)

$\mathrm{M}$ anure produced by swine contains an estimated $1.1 \mathrm{Tg}$ of $\mathrm{N}$ and $0.6 \mathrm{Tg}$ of $\mathrm{P}$ annually (Gollehon et al., 2001). These nutrients can serve as a crop fertilizer source when land applied. However, manure contains an N:P.ratio different from that required by a crop. Applying manure at rates required to meet the $\mathrm{N}$ needs of a crop typically results in accumulation of $\mathrm{P}$ in the surface soil. Excess nutrients concentrated at the soil surface are susceptible to removal by runoff (Eghball and Gilley, 1999). Sharpley. (1985) found that soil $P$ in the upper 1.3 to $37.4 \mathrm{~mm}$ of soil interacted with runoff water. Nutrient lost by leaching or runoff from agricultural fields represents a significant nonpoint source for impairing water quality (Sharpley et al., 1998).

Improving the bioavailability of $\mathbf{P}$ contained in feed grain is one approach for reducing the $P$ content of swine manure. Addition of the enzyme phytase or feeding grain that contains $\mathrm{P}$ in an available form is a way of improving bioavailability. Low-

USDA-ARS, Agroecosystem Management Research Unit, Lincoln. NE 68583. Dr. Brian J. Wienhold is corresponding author. E-mail: brian.wienhold@ ars.usda.gov

Reccived February 5, 2010

Accepted for publication March 26, 2010

U.S. Department of Agriculture, Agriculture Research Service, Northem Plains Area, is an equal-opportunity/affirmative action employer, and all services are available without discrimination.

Trade or manufacturess' names mentioned do not constitute endorsement, recommendation, or exclusion by the USDA-ARS

Copyright 02010 by Lippincott Williams \& Wilkins

ISSN: 0038-075X

DOl: $10.1097 / \mathrm{SS} .0 \mathrm{~b} 013 \mathrm{e} 3181 \mathrm{e} 055 \mathrm{ed}$ phytate corn (LPC) contains similar amounts of total P as traditional corn (TC) but a greater proportion of that $P$ presents as phosphate than phytate (Ertl et al., 1998). Use of LPC in swine diets has been shown to reduce the total $P$ content of manure, implying that environmental benefits may result from adoption of this technology (Baxter et al., 2003). Addition of LPC and TC swine manure at rates to meet the $\mathrm{N}$ needs of a crop raised soil-extractable $P$, but the increase was less for LPC manure than for TC manure (Wienhold, 2005). Greenhouse and field studies have demonstrated that the use of LPC in swine diets reduces the $P$ content but does not affect the availability of that P (Gollany et al., 2003; Paschold et al., 2008a).

A comparison of runoff losses of $P$ from soils receiving manure from either LPC diets or TC diets has been conductcd for poultry litter and swine slurry. Penn et al. (2004) reported that total $\mathrm{P}$ and dissolved $\mathrm{P}$ were lower in manure from turkeys fed LPC diets than those fed TC diets, but when applied to tall fescue [Lolium arundinaceum (Schreb.) Darbys.] plots, dissolved $P$ in runoff generated the day after application was greater for the LPC treatment. In contrast, Smith et al. (2004a) reported that total and dissolved P were lower in litter from poultry fed LPC diets than in those fed TC diets, and when applied to tall fescue plots, dissolved $P$ in runoff generated the day after application was lower for the LPC treatment. Surface application of swine slurry produced from LPC or TC dicts resulted in similar runoff losscs of dissolved $\mathrm{P}$ generated immediately after slurry application (Gilley et al., 2001). All of these studies were conducted using rainfall simulators that represent a worst-case scenario for generating runoff and sediment. Because precipitation is highly variable, several years may be required to assess management effects on runoff under natural conditions (Menjoulet et al, 2009). The objective of this study was to compare runoff losses of $\mathrm{N}$ and $\mathrm{P}$ from no-tillage sorghum plots receiving inorganic fertilizer, manure from swine fed an LPC diet, or manure from swine fed a TC diet during three consecutive growing seasons under natural rain-fed conditions.

\section{MATERIALS AND METHODS}

\section{Swine Feed Preparation}

Corn exhibiting the low-phytate trait (Pioneer variety $\mathrm{X}(127 \mathrm{PP})$ and the same variety without the low-phytate trait (Pioneer variety Alicia) were grown under irrigation near Shelton, NE, in 1998. Recommended practices for irrigation, fertilizer application, and pest control were used to optimize yield. The stands were harvested and stored scparately until used as feed. The two com sources were used to prepare feed appropriate for a starter-phase swine diet in the spring of 1999 , 2000 , and 2001. Each year, the two diets were fed to swine in elevated pens with 10 pigs per pen. Each diet was fed to all pigs in six randomly assigned pens. Trays were placed under each pen, and slurry (manure and urine) was collected. Slurry from swine fed each of the two diets was stored separately until needed for field application. A representative TC slurry sample contained $3.6 \% \pm 0.9 \%$ dry matter and on a dry-weight basis 
had an $\mathrm{N}$ concentration of $108.8 \pm 13.0 \mathrm{~g} \mathrm{~kg}^{-1}$ and a $\mathrm{P}$ concentration of $33.6 \pm 1.1 \mathrm{~g} \mathrm{~kg}^{-1}$. A representative LPC slurry sample containcd $7.2 \%{ }^{7} \pm 0.6 \%$ dry matter and on a dry-weight basis had an $N$ concentration of $90.1, \pm, 11.6 \mathrm{~g} \mathrm{~kg}^{-1}$ and $\mathrm{a}$ $P$ concentration of $19.8 \pm .2 \mathrm{~g} \mathrm{~kg}^{-1}$. Approximately $60 \%$ of manure $\mathrm{P}$ is water extractable in both manure types (Wienhold and Miller, 2004).

\section{Site Description and Experimental Design}

The field site was located at the Rogers. Memorial Research Farm $18 \mathrm{~km}$ east of Lincoln, NE. Soil at the Rogers Farm was an Aksarben (formerly Sharpisburg) silty clay loam (fine smectitic, mesic, Typic Argiudoll) on a $3 \%$ to $5 \%$ slope. When this study was initiated, the soil had a total $\mathrm{N}$ concentration of $1.0 \mathrm{~g} \mathrm{~kg}^{-1}$, an organic $C$ concentration of $10.2 \mathrm{~g} \mathrm{~kg}^{-1}$, Bray $P$ concentration of $7.8 \mathrm{mg} \mathrm{kg}$, a bulk density of $1.36 \mathrm{~g} \mathrm{~cm}^{-3}$, and a $\mathrm{pH}$ of 5.7 in the 0- to 15-cm depth (Wienhold, 2005).

The site has been in a no-tillage winter wheat (Triticum aestivum L.), soybiean [Glycine max (L.) Merr.], sorghum [Sorghum bicalor (L.) Moench] rotation for more than 10 years and was in the sorghum phase of the rotation in the year before the initiation of this study. The site had no known history of manurc application. Nine runoff plots $(3.6 \times 9.7 \mathrm{~m})$ were established by installing metal borders on the upslope end and sides and a collection trough on the downslope end. The long side of the plot was parallel to the slope. Runoff and sediment generated from a plot during a precipitation event flowed into the collection trough, through a pipe, and into a container. Three nutrient treatments (inorganic fertilizer, LPC manure, and TC manure) were assigned to the plots in a completely randomized design with three replications. The inorganic fertilizer treatment received $120 \mathrm{~kg} \mathrm{~N}$ ha' as $\mathrm{NH}_{4} \mathrm{NO}_{3}$ and $30 \mathrm{~kg} \mathrm{Pha}^{-1}$ as superphosphate. This treatment served as the control because sorghum biomass production is reduced with no fertilization (Paschold et al., 2008b) and reduced surface crop residuc could potentially result in increased runoff. In addition, previous research has documented that $P$ contained in fertilizer and manure contribute more to runoff loss of $P$ than antecedent soil $P$ (Smith et al., 2004b). Both manures were added at rates required to meet the $\mathrm{N}$ needs of sorghum, assuming $70 \%$ of the $\mathrm{N}$ in the manure was available to the crop during the growing season (Koelsch and Shapiro, 1997). The two manures differed in nutrient concentration (Wienhold and Miller, 2004). This difference resulted in different $P$ application rates (Table 1). Manurc nutrient concentration was determined before application for estimating application rates and also at the time of application for calculation of actual application rates (Table 1). Differences in nutrient content between these two sampling times caused by changes during storage and variation in mixing of the slurry beforc samiple collcction affected the actual amount applied. Sorghum was direct-seeded into the previous year residue, and : treatments were surface applied at crop emergence.

\section{Runoff, Sediment, and Chemical Analysis}

Precipitation was recorded by an automated rain gauge (Onset Corp, Boumc, MA) at the site. For precipitation events that generated runoff, the volume of runoff was recorded, sediment was resuspended, and duplicate samples were collected for determination of sediment content and chemical analysis. Samples were collected for all runoff events from the time nutrient treatments were applied in the spring until crop harvest in the fall of each year. For each rumoff event, a subsample of runoff was placed in a drying bottle, weighed, dried, and rcweighed to determine sediment mass. Runoff and erosion amounts wcre
TABLE 1. Swine Slurry, Total N, and Total P Application Rates for the Rogers Memorial Farm Located Near Lincoln, NE

\begin{tabular}{|c|c|c|c|}
\hline \multirow{2}{*}{ Rogers Farm } & \multicolumn{3}{|c|}{ Nutrient Source ${ }^{\dagger}$} \\
\hline & TC & LPC & IF \\
\hline \multicolumn{4}{|l|}{1999} \\
\hline Slursy, $\mathrm{Mg} \mathrm{ha}-1$ & 25.5 & 25.5 & 一 \\
\hline $\mathrm{N}, \mathrm{kg} \mathrm{ha}^{-1}$ & 112 & 88 & 123 \\
\hline $\mathrm{P}, \mathrm{kg} \mathrm{ha}^{-1}$ & 43 & 30 & 30 \\
\hline \multicolumn{4}{|l|}{2000} \\
\hline Slurry, $\mathrm{Mg} \mathrm{ha}{ }^{-1}$ & 35.1 & 20.7 & 一 \\
\hline $\mathrm{N}, \mathrm{kg} \mathrm{ha}^{-1}$ & 258 & 194 & 123 \\
\hline $\mathrm{P}, \mathrm{kg} \mathrm{ha}^{-1}$ & 57 & 34 & 30 \\
\hline \multicolumn{4}{|l|}{2001} \\
\hline Slurry, $\mathrm{Mg} \mathrm{ha}^{-1}$ & 30.0 & 24.1 & 一 \\
\hline $\mathrm{N}, \mathrm{kg} \mathrm{ha}^{-1}$ & 120 & 121 & 123 \\
\hline $\mathrm{P}, \mathrm{kg} \mathrm{ha}^{-1}$ & 40 & 31 & 30 \\
\hline
\end{tabular}

${ }^{\dagger} \mathrm{TC}$ : manure from swine fed a traditional com diet; LPC: manure from swine fed a low phytate com diet; IF: inorganic fertilizer.

calculated based on the volume of water, mass of sediment, and plot arca. Chemical analysis included colorimetric determination of total $\mathrm{P}$ in nitric acid-perchloric acid digests (Johnson and Ulrick, 1959), total $N$ using the Dumas imethod (Tate, 1994), electrical conductivity using a conductivity meter, $\mathrm{pH}$ using a glass electrode (Smith and Doran, 1996) in unfiltered subsamples, dissolved P using the phosphomolybdate blue method (Murphy and Riley, 1962), and inorganic $N$ using the $C d$ reduction method (Mulvaney, 1996) in subsamples that were centrifuged and filtered. Nutrient loss was calculated based on nutrient concentration, runoff volume, and plot area. Because the amount of $\mathrm{N}$ and $\mathrm{P}$ applied differed among treatments, nutrient loss was also expressed as a percentage of applied $N$ and $P$.

\section{Statistical Analysis}

Runoff, sediment, and nutrient loss were compared among treatments by a completely random repeated-measures model in PROC MTXED of SAS (Littell et al., 1996). Differences were considered significant at the 0.05 probability level. Differences among means were determined by pairwise comparisons made with the DIFF option of the LSMEANS statement. The Tukey adjustment option of the LSMEANS statement was used to protect the experiment-wise error rate.

\section{RESULTS}

Precipitation received during the runoff assessment period of each year was similar ( $32 \mathrm{~cm}$ in $1999,30 \mathrm{~cm}$ in 2000 , and $35.5 \mathrm{~cm}$ in 2001 ). However, the intensity and duration of individual precipitation events were highly variable. In 1999, nearly half of the precipitation received during the growing season fell during the first two events (Fig. 1). In 2000 and 2001, numerous small precipitation events occurred at the beginning of the growing season. These precipitation patterns are characteristic of the continental climate present in this region (Hershfield, 1961).

The observed precipitation patterns exerted a strong influence on runoff from the plots (Fig. 2). Runoff differed among years $(P<0.0001)$ and was greatest in 1999 and lowest in 2001. In 1999, the two initial precipitation events generated most of the observed runoff. In $2000,80 \%$ of the observed runoff resulted 


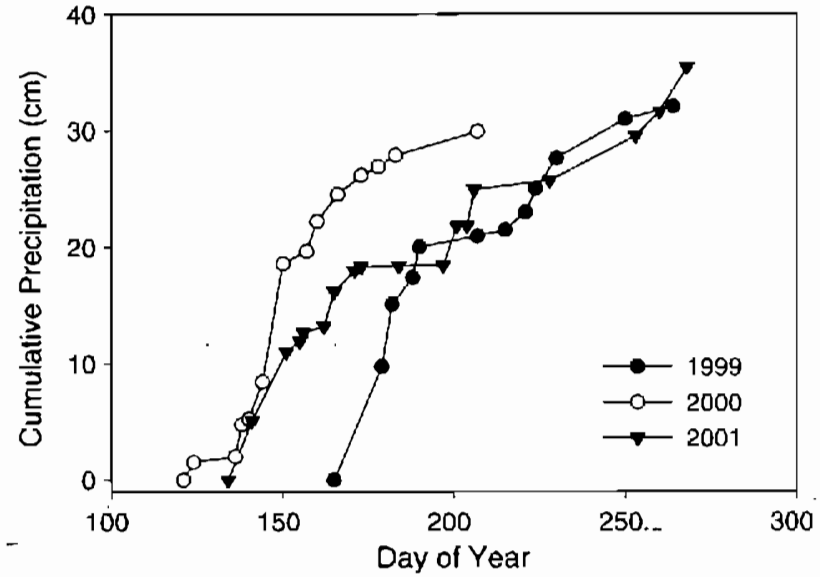

FIC. 1. Cumulative precipitation as a function of year at the Rogers Memorial Research Farm located near Lincoln, NE.

from a single precipitation cevent on Day 150. In 2001, precipitation was charactcrized by numerous small events that generated minimal runoff. When expressed as a percentage of precipitation received, runoff amounted to $8 \%$ of precipitation in $1999,4 \%$ of precipitation in 2000 , and less than $1 \%$ of precipitation in 2001 . In addition to precipitation intensity and duration, management also affects the incidence and volume of nunoff. Crop residuc retained on the soil surface with no-tillage has been found to maintain soil structure and infiltration capacity (Rousseva, 1989) and contributed to the low runoff volumes measured in this study. Others have also reported low runoff volumes under natural rainfall from untilled plots (Menjoulet ct al., 2009).

There was little variation in $\mathrm{pH}$ and electrical conductivity among treatments or years. Mean runoff $\mathrm{pH}$ was $6.5 \pm 0.3$, and $\mathrm{EC}$ was $0.09 \pm 0.06 \mathrm{dS} \mathrm{m}{ }^{-1}$. Based on measured $\mathrm{pH}$ and electrical conductivity, the runoff from plots in this study would not be expected to substantially impact receiving water bodies. The near-neutral $\mathrm{pH}$ and low electrical conductivity values reflect the low nutrient loads discussed later for runoff in this study.

Flow-weighted concentrations (FWC) of nutrients in runoff from the plots did not differ among treatments $(P>0.05)$, and

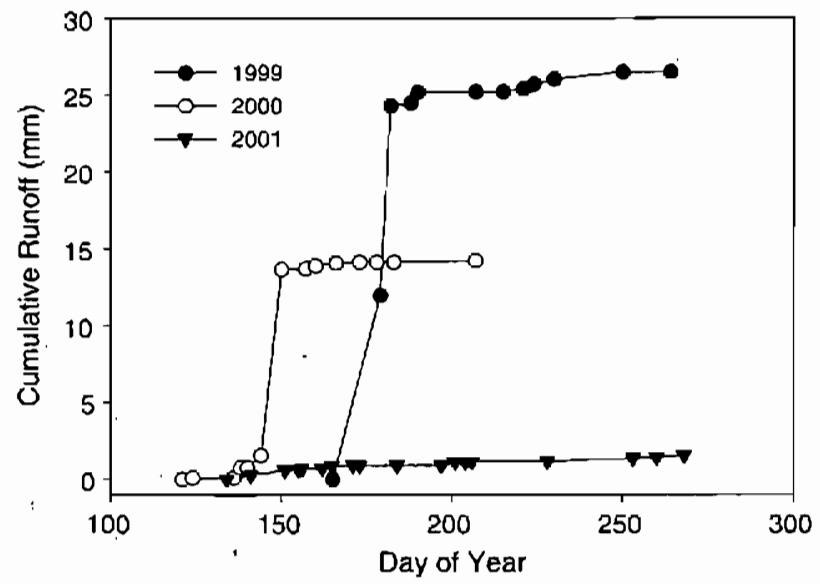

FIG. 2. Cumulative runoff as a function of year at the Rogers Memorial Research Farm located near Lincoin, NE.
TABLE 2. Flow-Weighted Concentration (Mean $\pm \mathrm{SE}$ ) of Nutrients in Runoff as a Function of Year at the Rogers Memorial Farm Located Near Lincoln, NE

\begin{tabular}{|c|c|c|c|c|}
\hline \multirow[b]{3}{*}{ Nutrient } & \multicolumn{3}{|c|}{ Year } & \multirow[b]{3}{*}{$\boldsymbol{P}$} \\
\hline & 1999 & 2000 & 2001 & \\
\hline & \multicolumn{3}{|c|}{ 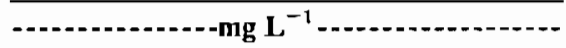 } & \\
\hline Dissolved P & $1.61 \pm 0.24 \mathrm{~A}^{\dagger}$ & $0.93 \pm 0.09 \mathrm{~B}$ & $5 \mathrm{~A}$ & 0.01 \\
\hline Total P & $2.82 \pm 0.23 \mathrm{~A}$ & $1.91 \pm 0.23 \mathrm{~B}$ & $1.59 \pm 0.23 \mathrm{~B}$ & 0.00 \\
\hline $\mathrm{NO}_{3}-\mathrm{N}$ & $4.81 \pm 0.77 \mathrm{~A}$ & $1.79 \pm 0.22 \mathrm{~B}$ & $1.01 \pm 0.28 \mathrm{~B}$ & 0.002 \\
\hline $\mathrm{NH}_{4}-\mathrm{N}$ & $1.28 \pm 0.11 \mathrm{~A}$ & $0.56 \pm 0.04 \mathrm{~B}$ & $2.61 \pm 0.61 \mathrm{~A}$ & $<0.00$ \\
\hline Total N & $57.1 \pm 2.54 \mathrm{~A}$ & $13.1 \pm 1.42 \mathrm{~B}$ & $44.6 \div 9.09 \mathrm{~A}$ & $<0.00$ \\
\hline
\end{tabular}

${ }^{\dagger}$ Values within a row followed by different letters differ at $P<0.05$.

there was no interaction between treatment and years $(P>0.05)$. The FWC of dissolved $P$ was greater in 1999 and 2001 than in 2000 (Table 2). The dissolved P FWC was great enough to contribute to eutrophication of receiving water bodies in all 3 years (Correll, 1998). The FWC of total P was greater in 1999 than in 2000 or 2001 . A maximum contaminant level for $\mathrm{NO}_{3}-\mathrm{N}$ of $10 \mathrm{mg} \mathrm{L}^{-1}$ has been established for drinking water (USEPA, 2006). Although $\mathrm{FWC}$ of $\mathrm{NO}_{3}-\mathrm{N}$ was greater in 1999 than in 2000 or 2001 , the maximum contaminant level was not exceeded during the study. Nitrate- $\mathrm{N}$ has also been implicated as contributing to the hypoxic zones in aquatic ecosystems at concentrations as low as $2 \mathrm{mg} \mathrm{L}^{-1}$ (Turner et al., 1997). The FWC of $\mathrm{NH}_{4}-\mathrm{N}$ and total $\mathrm{N}$ was greater in 1999 and 2001 than in 2000. The FWC of $\mathrm{NH}_{4}-\mathrm{N}$ in 2001 exceeded the $2.5 \mathrm{mg} \mathrm{L}^{-1}$ concentration identified as adversely affecting aquatic organisms (USEPA, 1986). Flow-weighted concentrations of nutrients tended to be greater in 1999 and 2001 when a significant amount of runoff was gencrated shortly after treatment application $(90 \%$ during the first two precipitation events in 1999 and 30\% during the first two precipitation events in 2001) compared with 2000 when several precipitation events occurred before nunoff occurred. Smith et al. (2007) reported rapid declines in FWC of dissolved $\mathrm{P}$ and $\mathrm{NH}_{4}-\mathrm{N}$ as a function of days after swine slurry application. Infiltration of slurry into the soil after application and leaching of nutrients into the soil by non-runoff-producing precipitation events reduces the likelihood of subsequent runoff losses of nutrients.

Sediment loss differed among years $(P<0.0001)$ and was greatest in 1999 and lowest in 2001 (Fig. 3A). Runoff and sedimcnt loss were strongly correlated (Table 3). The mass of sediment lost from these no-tillage plots was small and less than what is considered acceptable for soil conservation. Reduced sediment loss under no-tillage has been well documented (Römkens et al., 1973). In no-tillage fields; surface soil has greater organic matter content and has an increasc in water-stable aggregates that results in increased porosity, higher infiltration, and reduced susceptibility to erosion (Rhoton et al., 2002; Pikul et al., 2007).

Dissolved $P$ loss differed among years $(P<0.0001)$ and was greater in 1999 and 2001 than in 2000 (Fig. 3B). Dissolved $P$ was negatively correlated with runoff (Table 3) and was numerically greater in 2001 when runoff was lowest than in 1999 when runoff was greatest. Total $P$ loss differed among years $(P<0.0001)$ and was greater in 1999 and 2001 than in 2000 (Fig. 3C). Total P loss was correlated with dissolved P loss (Table 3). Dissolved P was $41 \%$ of total $P$ in $1999,54 \%$ of total $P$ in 2000 , and $88 \%$ of total $P$ in 2001 . These percentages are 

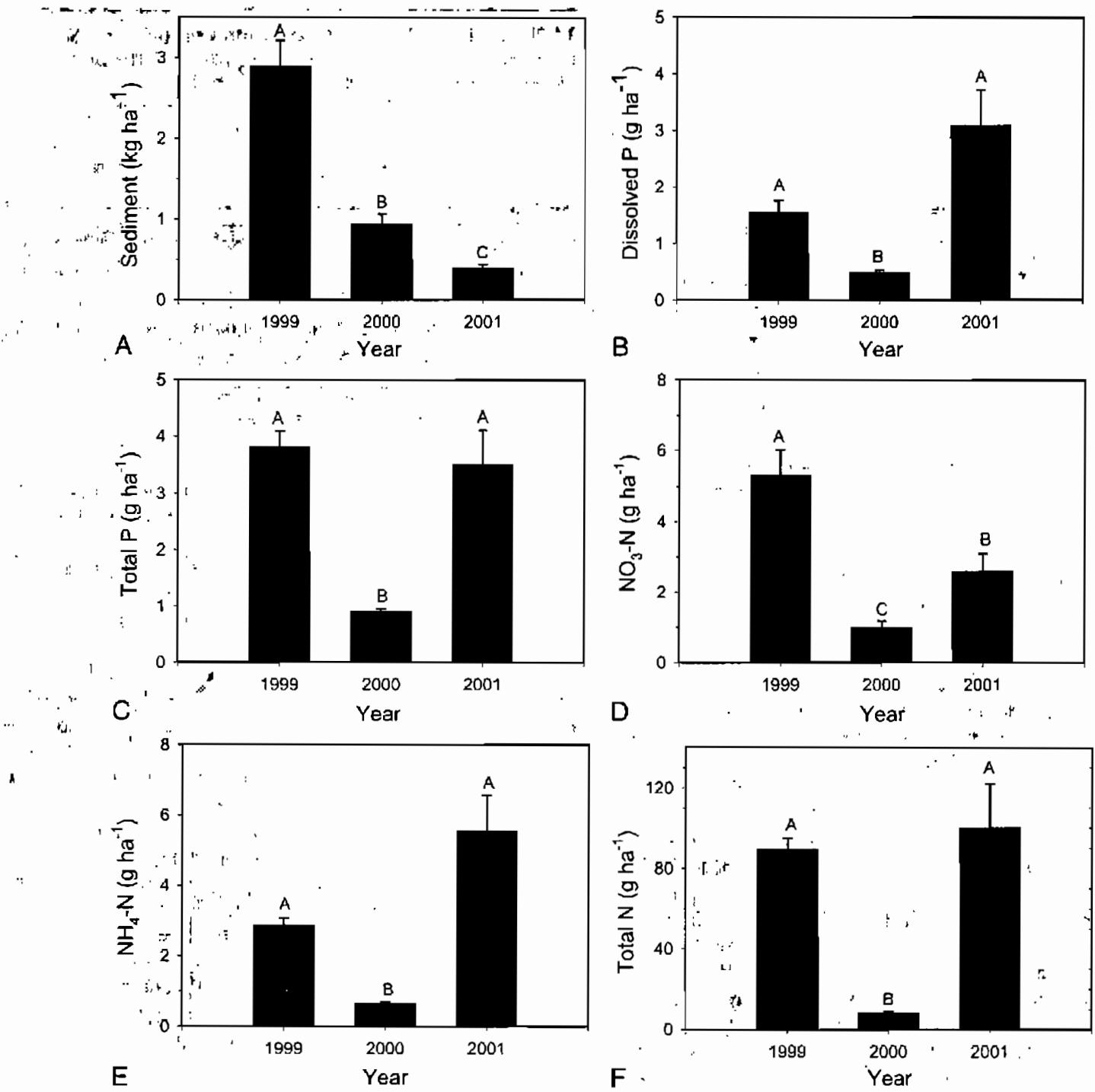

FIG. 3. Mass of sediment (A), dissolved $P(B)$, total $P(C), N O_{3} \cdot N(D), N H_{4}-N(E)$, and total $N(F)$ lost in runoff as a function of year at the Rogers Memorial Research Farm located near Lincoin, NE. Error bars represent 1 SE. Within a panel, bars with different letters above them are significantly different a $P<0.05$.

similar to the results of Kleinman et al. (2002) who reported dissolved $\mathrm{P}$ amounts that were $35 \%$ to $72 \%$ of total $\mathrm{P}$ for selected soils receiving surface-applied swine slurry. The rclatively large amount of dissolved and total P lost in 1999 and 2001 resulted when runoff-producing precipitation occurred shortly after slurry application (Fig, 2). In contrast, in 2000, there were several precipitation events that did not produce runoff before the first runoff event. Early-season precipitation likely leached the slurry into the soil where it became less susceptible to loss during subsequent nunoff events. Others have also reported declining $\mathrm{P}$ loss during successive precipitation events or time since slurry application (Allen and Mallarino, 2008; Kleinman and Sharpley, 2003). When expressed as a percentage of $P$ applied, loss of total $\mathrm{P}$ or dissolved $\mathrm{P}$ did not differ among treatments $(P>0.05)$ nor was there a treatment by year interaction $(P>0.05)$. There were statistical differences among years $(P<0.0001)$ in the percentage of $P$ applied that was lost; however, the mass of dissolved or total $P$ lost in runoff was small and represented much less than $1 \%$ of the $P$ applied on any of the treatments during this study. In contrast, $P$ contained in the grain at harvest represented $25 \%$ to $57 \%$ of that applied (Paschold et al., 2008b).

The mass of $\mathrm{NO}_{3}-\mathrm{N}$ lost in runoff differed among ycars $(P=0.003)$ and declined in the order $1999>2001>2000$ (Fig. 3D). Mass of $\mathrm{NO}_{3}-\mathrm{N}$ lost was corrclated with runoff, sediment loss, and total $\mathrm{P}$ loss (Table 3). Loss of $\mathrm{NH}_{4}-\mathrm{N}$ and total $\dot{N}$ in nunoff differcd among years $(P<0.0001)$ and was greater in 1999 and 2001 than in 2000 (Figs. 3E, F). Mass of $\mathrm{NH}_{4}-\mathrm{N}$ lost was correlated with loss of dissolved $P$ and total $P$ (Table 3). Total $\mathrm{N}$ loss was correlated with loss of dissolved $\mathrm{P}$, total $\mathrm{P}$, $\mathrm{NO}_{3}-\mathrm{N}$, and $\mathrm{NH}_{4}-\mathrm{N}$ (Table 3 ). When expressed as a percentage of $\mathrm{N}$ applied, loss of $\mathrm{NO}_{3}-\mathrm{N}, \mathrm{NH}_{4}-\mathrm{N}$, and total $\mathrm{N}$ did not differ among treatments $(P>0.05)$ nor was there a treatment $x$ year interaction $(P>0.05)$. There werc statistical differences among years $(P<0.001)$ in the percentage of $\mathrm{NO}_{3}-\mathrm{N}, \mathrm{NH}_{4}-\mathrm{N}$, and total $\mathrm{N}$ applied that was lost; however, the mass of $\mathrm{NO}_{3}-\mathrm{N}, \mathrm{NH}_{4}-\mathrm{N}$, 
TABLE 3. Correlation and P Values among Runoff, Sediment, and Nutrient Losses from Plots Receiving Inorganic Fertilizer or Manure From Swine Fed Traditional or Low-Phytate Corn Diets at the Rogers Memorial Research Farm Located Near Lincoln, NE

\begin{tabular}{|c|c|c|c|c|c|c|c|}
\hline & Runoff & Sediment & Dissolved P & Total P & $\mathrm{NO}_{3}-\mathrm{N}$ & $\mathrm{NH}_{4}-\mathrm{N}$ & Total $\mathrm{N}$ \\
\hline \multirow[t]{2}{*}{ Runoff } & 1.00 & 0.86 & -0.38 & 0.10 & 0.53 & -0.37 & -0.05 \\
\hline & & $<0.0001$ & 0.05 & 0.62 & 0.004 & 0.06 & 0.79 \\
\hline \multirow[t]{2}{*}{ Sediment } & & 1.00 & -0.14 & 0.35 & 0.64 & -0.10 & 0.19 \\
\hline & & & 0.50 & 0.07 & 0.0003 & 0.61 & 0.35 \\
\hline \multirow[t]{2}{*}{ Dissolved P } & & & 1.00 & 0.57 & 0.24 & 0.78 & 0.51 \\
\hline & & & & 0.002 & 0.22 & $<0.0001$ & 0.006 \\
\hline \multirow[t]{2}{*}{ Total P } & & & & 1.00 & 0.69 & 0.72 & 0.85 \\
\hline & & & & & $<0.0001$ & $<0.0001$ & $<0.0001$ \\
\hline \multirow[t]{2}{*}{$\mathrm{NO}_{3}-\mathrm{N}$} & & & & & 1.00 & $\cdot 0.38$ & 0.61 \\
\hline & & & & & & 0.06 & 0.0008 \\
\hline \multirow[t]{2}{*}{$\mathrm{NH}_{4}-\mathrm{N}$} & & . & & & & 1.00 & 0.83 \\
\hline & & & & & & & $<0.0001$ \\
\hline Total N & & & & & & & 1.00 \\
\hline
\end{tabular}

and total $\mathrm{N}$ lost in runoff was small and represented much less than $1 \mathrm{II} / \mathrm{o}$ of the $\mathrm{N}$ applied on any of the treatments during this study. As with $P$, the amount of $\mathrm{N}$ used by the crop was much greater ( $54 \%$ to $61 \%$ of applied $N$ ) than that lost (Paschold et al.: $2008 \mathrm{~b}$ ).

\section{DISCUSSION}

Runoff losses of nutrients are a concern because of potential adverse effects on the environment or human and aquatic health. Runoff losses of soluble $\mathrm{P}$ and total $\mathrm{N}$ are closely related to soil test values, and models have been developed to predict runoff losses of these nutrients using measured soil nutrient values (Sharpley, 1985). Nitrate losses are more difficult to predict because $\mathrm{NO}_{3}-\mathrm{N}$ is readily leached into the soil and is then less susceptible to runoff loss. Given the role of $\mathrm{P}$ in cutrophication, there have been regulatory efforts to limit soil $\mathrm{P}$ levels to protect the environment. Addition of fertilizer or manure increases runoff nutrient loss over soil test levels (Smith et al., 2004b), and management options are needed to reduce these losses. Results presented demonstrate that runoff and nutrient loss are low for swine manure applied to no-tillage crops. Management practices that maintain crop residue, soil structure, and infiltration reduce runoff losses.

Use of LPC in swine diets results in manure that has a lower $\mathrm{P}$ content than manure from swine fed TC diets (Wienhold and Miller, 2004). As previously reported, this reduction in manure $P$ content did not result in a reduction in loss of $P$ in runoff when compared with inorganic fertilizer or TC manure under no-tillage conditions. These results agree with a rainfall simulation study that. compared sediment and nutrient losses of three soils receiving swine slurry from animals fed TC diets, LPC diets, or diets supplemented with phytase (Gilley et al., 2001). Use of LPC or phytase reduced the P content of manure but did not reduce the concentration or total amount of $P$ lost in runoff compared with TC manure. In contrast, although addition of LPC and TC swine manure raised soil-extractable $P$, the increase was less for LPC manure than for TC manure (Wienhold, 2005). Use of LPC in swine diets results in manure having an $\mathrm{N}: \mathrm{P}$ content more similar to the $\mathrm{N}: \mathrm{P}$ needs of a crop than $\mathrm{TC}$ manure. When LPC manure is applied at rates required to meet the $\mathrm{N}$ needs of the crop, soil test $\mathrm{P}$ increases less than for manure from swine fed a TC diet. When LPC manure is applied at rates needed to meet $\mathrm{P}$ crop requirements, less supplemental $\mathrm{N}$ would be necessary than for TC manure. Use of LPC results in more efficient use of $\mathbf{P}$ in animal-crop production systems.

\section{ACKNOWLEDGMENTS}

The authors thank Julie Paschold, Andrew Pond, Lauren Rock, Susan Siragusa-Ortman, and Susan Wagner for field and technical assistance; Rick and Jeff Pope for access to their swine operation; Cliff Hunter (deceased) for maintaining the field site; and Pioneer Hi-Bred for providing seed.

\section{REFERENCES}

Allen, B. L., and A. P. Mallarino. 2008. Effect of liquid swine manure rate. incorporation, and timing of rainfall on phosphorus loss with surface runoff. J. Environ. Qual. 37:125-137.

Baxter, C. A., B. C. Joern, D. Ragland, J. S. Sands, and O. Adeola. 2003. Phytase, high-availablc-phosphorus corn, and storage effects on phosphorus levels in pig excreta. J. Environ. Qual. 32:1481-1489.

Correll, D. L. 1998. The role of phosphorus in the eutrophication of receiving waters: A review. J. Environ. Qual. 27:261-266.

Eghball, B., and J .E. Gilley. 1999. Phosphorus and nitrogen in runoff following beef cattle manure or compost application. J. Environ. Qual. 29:15-23.

Er1, D. S., K. A. Young, and V. Raboy. 1998. Plant genetic approaches to phosphorus management in agricultural production. J. Environ. Qual. 27:299-304.

Giliey, J. E., B. Eghball, B. J. Wienhold and P. S. Miller. 2001. Nutrients in runoff following the application of swine manure to interrill areas. Trans. ASAE. 44:1651-1659.

Gollany, H. T., M. A. Schmitt, P. R. Bloom. G. W. Randall, and P. R. Carter. 2003. Extractable phosphorus following soil amendment with manure from swine fed low-phytate com. Soil Sci. 168:606-616.

Gollehon, N., M. Caswell, M. Riboudo, R. Kellogg, C. Lander and D. Letson. 2001. Confined Animal Production and Manure Nutrients. Agric. Inf. Bull. 771. USDA Exon. Res. Sery., Washington, DC.

Hershfield D. M. 1961. Rainfall Frequency Atlas of the United Staces. Tech. Pap. No. 40. Weather Bureau, U.S. Dept. of Commerce, Washington, DC.

Johnson, C. M., and A. Ulrick. 1959. Analytical Methods for Use in Plant Analysis. Agric. Exp. Stn. Bull. 766. Univ. of California, Berkeley, CA.

Kleinman, P. J. A., and A. N. Sharpley. 2003. Effect of broadcast manure on runoff phosphorus concentralions over successive rainfall events. J. Environ. Qual. 32:1072-1081. 
Kleinman, P. J.:A.-A. N. Sharpley, B. G.: Moyer, and G. F. Elwinger. 2002. Effect of minerál and manure phosphorus sources on runoff phosphorus.

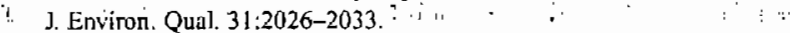

Koelsch, R.. and C. Shapiro. 1997. Determining Crop Available Nutrients From Manure. NebGuide G97-1335-A. University. of Nebraska; Lincoln, NE.

Littcll; R. C., G. A. Milliken, W. W. Stroup, and R. D. Wolfinger. 1996. SAS "System for Mixed Modèls. SAS Institute, Inc, Cary, NC.

Menjoulet, B. C., K. R. Brye, A. L. Pirani; B. E. Haggard, and E. E. Gbur. 2009. Runoff water quality from broilér litter-amended tall fescue in Jesponse to natural precipitation in the Ozark highlands. J. Environ. Qual. $-38: 1005-1017$

Mulvariey, R. L. 1996.' Nitrogen - Inorganic forms. In Methods of Soil Analysis Part 3: Chemical Methods, Soil Sci. Soc. Am. Book Series No. 5. D.L. Sparks, et al, (eds.). Am. Soc. Agron., Madison, WI, pp. 1123-1184.

Murphy, J., and J: P. Riley. 1962. A modified single solulion method for the determination of phosphate in natural waters. Anal. Chim. Acta 27:31-36.

Paschold, J. S., B. J. Wienhold, D. L. McCallister, and R. B. Ferguson. 2008 a. Crop nitrogen and phosphorus utilization following application of slurry from sivine fed traditional or low phytate corn diets. Agron. J. 100: $997-1004$.

Paschold, J. S., B. J. Wienhold, R. B. Ferguson, and D. L. McCallister. 2008b. Soil nitrogen and phosphorus availability for field-applied slurry from swine fed traditional and low-phytate corn. Soil Sci. Snc. Am. J. 72 : 1096-1101.

Penn, C. J.: G. L. Mullins, L. W. Zelazny, J. G. Warren, and J. M. McGrath. 2004. Surface nunoff losses of phosphorus from Virginia soils amended wjth turkey manure using phytase and high available phosphorus corn diets. J. Environ. Qual. 33:1431-1439.

Pikul, J. L., Jr., S. Osborne, M. Ellsbury; and W. Riedell. 2007. Particulate organic matter and water-stable aggregation of soil under contrasting manàgement. Soil Sci. Soc. Am. J. 71:766-776.

Rhoton, F. E., M. J. Shipitilo, and D. T. Lindbo. 2002. Runoff and șoil loss from midwestern and southeastern US silt lnam soils as affected by tillage practice and soil organic matter content. Soil Tillage Res. 66:1-11.

$\because \cdots$, in

Römkens, M. J. M., D. W. Nelson, and V. J. Mannering. 1973. Nitrogen and phosphons composition of surface runoff as affected by tillage method. J. Environ. Qual. 2:292-295.
Rousseva, S. 1989. A laboratory index for soil crodibility assessment. Soil Technol. 2:287-299.

Sharpley, A. N. 1985. Depth of surface soil-runoff interaction as affected by rainfall, soil slope and management. Soil Sci. Soc. Am. J. 49: $1010-1015$.

Sharpley, A., J. J. Meisinger, A. Breeuwsma, J. T. Sims, T. C. Daniel. and J. S. Schepers. 1998. Impact of animal manure management on ground and surface water qualily. In Animal Waste Utilization: Effective Use of Manure as a Soil Resource. J.L. Hatlield and B.A. Stewan (eds.). Ann Arbor Press, Cheisea, MI, pp. 173-242.

Smith, D. R, P. A. Moore, Jr., D. M. Miles, B. E. Haggard, and T. C. Daniel. 2004a. Decreasing phosphorus runoff losses from land-applied poultry litter with dielary modifications and alum additions. J. Environ. Qual. 33:2210-2216.

Smith, D. R., P.:Ä. Moore, Jr, C. V. Maxwell, B. E. Haggard, and T. C. Daniel. 2004b. Reducing phosphorus runoff from swine manure with dietary phytase and aluminum chloride. J. Environ. Qual, 33:1048-1054.

Smith, D. R., P. R. Owens, A. B. Leytem, and E. A. Warnemuende. 2007. Nutrient losises from manure and fertilizer applications as impacted by time to first runoff event. Environ, Poliut. 147:131-137.

Smith, J. L., and J. W. Doran. 1996. Measurement and use of pH and clectrical conductivity for soil quality analysis. In Methods for Assessing Soil Qualiry. SSSA Spec. Publ. 49. J.W. Doran and A.J. Jones (eds.). SSSA, Madison, Wl, pp. 169-185.

Tate, D. F. 1994. Determination of nitrogen in fertitizer by combustion: Collaborative study. J. AOAC Intl. 77:829-839.

Turner, R. E.. N. N, Rabalais, Q. Dortch, D. Justic, and B. K. Gupta. 1997. Evidence for Nutrient Limitation on Sources Causing Hypoxia on the Louisianal Shelf. Proc. 1st Gulf of Mexico Hypoxia Management Conference. Cincinnati, OH. pp. 112-119.

USEPA. 1986. Quality Criteria for Water. EPA-440/586-001. Office of Water Regulation and Standards. Washingcion, DC.

USEPA. 2006. Drinking Water Contaminants: Available from: http:// www.epa.gov/safewater/contaminants/index.html\#mcls. USEPA, Washington, DC (verified July 28, 2009).

Wienhold, B. J. 2005. Changes in soil attributes following low phosphorus swine slurry application to no-tillage sorghum, Soil Sci. Sac. Am. J. 69:206-2L4

Wienhold, R. J., and P. S. Miller. 2004. Phosphorus fractionation in manure from swine fed traditional and low phytate corn dicts. J. Environ. Qual. 33:389-393. 